\title{
Psoriasin overexpression confers drug resistance to cisplatin by activating ERK in gastric cancer
}

\author{
LITING LI $^{1,2}$, YUXIN CUI $^{2}$, LIN YE $^{2}$, ZEHANG ZHAO ${ }^{2}$, WEN G. JIANG ${ }^{2}$ and JIAFU JI ${ }^{1}$ \\ ${ }^{1}$ Key Laboratory of Carcinogenesis and Translational Research, Department of Gastrointestinal Surgery, \\ Peking University Cancer Hospital and Institute, Peking University, Beijing 100142, P.R. China; \\ ${ }^{2}$ Cardiff China Medical Research Collaborative, Cardiff University School of Medicine, Heath Park, Cardiff CF14 4XN, UK
}

Received January 25, 2018; Accepted May 17, 2018

DOI: $10.3892 /$ ijo.2018.4455

\begin{abstract}
Psoriasin, a member of the S100 multigenic family, which is aberrantly expressed in a variety of human tumors, is considered as an attractive molecular target for cancer treatment. The present study aimed to characterize the role of psoriasin in gastric cancer (GC), the associated pathways through which it contributes to cancer development and progression, and the effect of psoriasin on cellular response to pre-operative chemotherapy in patients with GC. Expression of psoriasin mRNA and protein were analyzed using quantitative polymerase chain reaction and immunohistochemistry of gastric cancer cohorts, respectively. Gastric cancer cell models with differential expression of psoriasin were generated using stable cell lines that overexpressed psoriasin. The in vitro biological functions of the cells in response to psoriasin overexpression and to chemotherapeutic agents were assessed using various cell-based assays. Psoriasin was overexpressed in patients with advanced GC, and high psoriasin levels led to poor clinical outcomes. Increasing psoriasin expression in GC cell lines promoted cell proliferation, migration and invasion in vitro. Furthermore, psoriasin overexpression caused alterations in the levels of epithelial-mesenchymal transition-associated proteins, and activated the extracellular signal-regulated kinase signaling pathway. Additionally, higher levels of psoriasin expression were significantly associated a lack of response to neoadjuvant chemotherapy in patients with GC. Psoriasin overexpression tended to decrease the sensitivity
\end{abstract}

Correspondence to: Professor Jiafu Ji, Beijing Cancer Hospital and Key Laboratory of Carcinogenesis and Translational Research, Department of Gastrointestinal Surgery, Peking University Cancer Hospital and Institute, 52 Fucheng Road, Haidian, Beijing 100142, P.R. China

E-mail: jijiafu@hsc.pku.edu.cn

Professor Wen G. Jiang, Cardiff China Medical Research Collaborative, Cardiff University School of Medicine, Henry Wellcome Building, Heath Park, Cardiff CF14 4XN, UK

E-mail: jiangw@cf.ac.uk

Key words: psoriasin, gastric cancer, extracellular signal-regulated kinase, cisplatin of GC cells to cisplatin, potentially by inhibiting apoptosis or increasing the S-phase population. Taken together, these results indicate that psoriasin may be a promising therapeutic target for GC treatment, and a potential molecular marker to predict patient response to pre-operative chemotherapy.

\section{Introduction}

Gastric cancer (GC) currently ranks as the fourth most frequently diagnosed cancer and the second leading cause of mortality from malignant diseases worldwide (1). According to statistics, $>950$ 000 new GC cases are diagnosed every year, and an estimated 723,100 mortalities occurred in $2012(1,2)$. By the time of diagnosis, the majority of patients present with advanced GC, with a 5 -year survival rate of $<30 \%(3,4)$. Pre-operative chemotherapy has been successfully used in the treatment of locally advanced $\mathrm{GC}$, as it may increase the possibility of complete resection through shrinking the tumor (5). Based on clinical data, patients with GC that exhibit a positive response to neo-adjuvant chemotherapy can obtain a better prognosis than non-responders (5). However, different patients exhibit distinct therapeutic responses due to various genetic and epigenetic alterations that are involved in gastric tumorigenesis $(4,6)$. Therefore, a comprehensive understanding of the molecular variables that affect the GC disease pathway may contribute to identifying novel therapeutic targets or prognostic biomarkers that may help identify patients that are likely to benefit from chemotherapy.

Psoriasin, also termed S100A7, belongs to the S100 multigenic family of calcium-binding EF-hand proteins and was initially identified in 1991 as a highly expressed protein in psoriatic keratinocytes $(7,8)$. Psoriasin, a low molecular weight protein $(11.4 \mathrm{kDa})$, is localized in the cytoplasm, cell nucleus or secreted outside of the cell in certain cases $(9,10)$. Dysregulated expression of psoriasin has been observed in various types of cancer, including oral squamous cell carcinoma (11), breast cancer $(10,12)$, lung cancer (13), bladder cancer (14), skin cancer (15), head and neck cancer (16), prostate cancer (17) and cervical cancer (18). Functionally, psoriasin usually has malignant functions in cancer; however, it can also exhibit tumor suppressive effects in certain types of oral carcinoma and breast cancer by decreasing $\beta$-catenin activity $(11,12)$. Subsequent studies have suggested that intracellular and secreted forms of psoriasin protein have an important role in tumor development 
by regulating cell proliferation, metastasis, migration, invasion, apoptosis and angiogenesis (17-19). Mechanistically, several signaling pathways have been demonstrated to have a correlation with psoriasin, including Hippo, receptor for advanced glycation endproducts (RAGE), extracellular signal-regulated kinase (ERK), $\beta$-catenin and nuclear factor $(\mathrm{NF})-\kappa \mathrm{B}$ pathways. The downregulation of psoriasin in lung cancer suppresses cell growth and invasive potential by regulating NF- $\mathrm{BB}$ activity and the expression of matrix metalloproteinases and vascular endothelial growth factor (19). Similarly, psoriasin promotes cell survival by binding to c-Jun activation domain-binding protein1 and enhancing the phosphorylation of $\mathrm{NF}-\kappa \mathrm{B}$ and protein kinase B in breast cancer (20). Another study demonstrated that psoriasin binds to RAGE and activates ERK signaling to increase migration and invasion in cervical cancer (18).

However, the role of psoriasin in GC and its underlying mechanisms remain unclear. To the best of our knowledge, the present study is the first to characterize the expression of psoriasin in patients with GC and investigate the role of psoriasin in GC pathogenesis. Psoriasin was markedly upregulated in patients with GC and high expression of psoriasin was associated with poor survival. Furthermore, psoriasin positively regulated ERK signaling and promoted proliferation, migration and invasion. In addition, overexpression of psoriasin decreased the sensitivity of GC cells to cisplatin. Taken together, the findings suggested that psoriasin has a critical role in the pathogenesis of GC and may be a novel therapeutic target or a potential diagnostic marker for the patient response to pre-operative chemotherapy in GC.

\section{Materials and methods}

Cell line and cell culture. The human AGS (no. 89090402) and HGC-27 (no. 94042256) GC cell lines were purchased from the European Collection of Animal Cell Cultures (ECACC; Salisbury, UK). The cells were cultured in Dulbecco's modified Eagle's medium (DMEM)-F12 medium (Sigma-Aldrich; Merck KGaA, Darmstadt, Germany), supplemented with $10 \%$ fetal calf serum (FCS; Sigma-Aldrich; Merck KGaA) and $1 \%$ antibiotics (penicillin and streptomycin; Sigma-Aldrich; Merck $\mathrm{KGaA}$ ) at $37^{\circ} \mathrm{C}$ in a humidified $5 \% \mathrm{CO}_{2}$ atmosphere.

Patients and human GC tissue. Two cohorts were used in the present study, namely a generic collection and a collection with chemosensitive information. The first cohort had a total of $321 \mathrm{GC}$ tissues and 173 adjacent normal tissues were collected from patients with GC that underwent surgical resection, and some were treated with preoperative radiotherapy or chemotherapy at the Peking University Cancer Hospital (Beijing, China). Tissue and data were obtained between September 2003 and December 2007. The mean age of the patients in the cohort was 59.8 years with male/female ratio of 229:92 (Table I). The other cohort comprised of 87 patients with GC that had received chemotherapy with oxaliplatin/5-fluorouracil/leucovorin prior to surgery at the Peking University Cancer Hospital between December 2001 and November 2006. All of the tissues were stored immediately following surgery at $-80^{\circ} \mathrm{C}$ until use. Clinicopathological and follow-up information was obtained from patient data. GC staging was determined according to the 2010 tumor-nodemetastasis (TNM) classification recommended by the American
Table I. Association between psoriasin mRNA expression and clinicopathological features in gastric cancer tissues.

\begin{tabular}{|c|c|c|c|}
\hline Variable & $\mathrm{n}$ & $\begin{array}{c}\text { Psoriasin } \\
\text { expression } \\
\text { (median) }\end{array}$ & $\mathrm{P}$-value \\
\hline Tissue & & & $<0.001$ \\
\hline Tumor & 321 & 12.00 & \\
\hline Adjacent normal & 173 & 0.04 & \\
\hline Sex & & & 0.573 \\
\hline Male & 229 & 9.00 & \\
\hline Female & 92 & 13.00 & \\
\hline Depth of invasion & & & 0.011 \\
\hline $\mathrm{T} 1-2$ & 42 & 1.00 & \\
\hline T3-4 & 279 & 15.00 & \\
\hline Lymph node status & & & $<0.001$ \\
\hline No & 71 & 0.03 & \\
\hline $\mathrm{N} 1+2+3$ & 250 & 16.00 & \\
\hline Distant metastasis & & & $<0.001$ \\
\hline M0 & 280 & 4.00 & \\
\hline M1 & 41 & 384.00 & \\
\hline TNM staging & & & $<0.001$ \\
\hline $\mathrm{I}+\mathrm{II}$ & 85 & 1.00 & \\
\hline III+IV & 236 & 17.00 & \\
\hline \multicolumn{4}{|l|}{ Differentiation } \\
\hline High & 1 & 0.15 & \\
\hline High-medium & 21 & 20.00 & \\
\hline Medium & 67 & 15.00 & $0.629^{\mathrm{a}}$ \\
\hline Medium-low & 87 & 13.00 & $0.732^{\mathrm{a}}$ \\
\hline Low & 145 & 3.00 & $0.453^{\mathrm{a}}$ \\
\hline Clinical outcome & & & $<0.001$ \\
\hline Alive & 134 & 1.00 & \\
\hline Died & 187 & 25.00 & \\
\hline
\end{tabular}

${ }^{a}$ Compared with high-medium differentiation; Mann-Whitney U test for comparisons between two groups; Kruskal-Wallis test for multiple group followed Tukey honest significant difference as post hoc test. TNM, tumor-node-metastasis.

Joint Committee on Cancer (AJCC 7th edition) (21). This study was approved by Peking University Cancer Hospital Research Ethics Committee (ethics no. 2006021) and written consent was obtained from all patients involved.

RNA isolation, reverse transcription, conventional polymerase chain reaction (PCR) and quantitative PCR ( $q P C R)$. Total RNA was extracted from cells or homogenized tissues using TRI reagent (Sigma-Aldrich; Merck KGaA) following the manufacturer's instructions, and subsequently reverse transcribed into cDNA using Promega Reverse Transcription kit (Promega Corporation, Madison, WI, USA). The reverse transcription conditions were annealing at $25^{\circ} \mathrm{C}$ for $5 \mathrm{~min}$, extension at $42^{\circ} \mathrm{C}$ for $60 \mathrm{~min}$, and inactivation at $70^{\circ} \mathrm{C}$ for 15 . PCR was then performed using GoTaq Green MasterMix (Promega Corporation) under the cycling conditions as follows: 
Table II. Primers sequences.

\begin{tabular}{lll}
\hline Name & \multicolumn{1}{c}{ Forward } & \multicolumn{1}{c}{ Reverse } \\
\hline Psoriasin & ATGAGCAACACTCAAGCTG & ACTGGCTGCCCCCGGAACA \\
Psoriasin (qPCR) & TGTGACAAAAAGGGCACAAA & ACTGAACCTGACCGTACACCCAGCAAGGACAGAAACTC \\
Snail & CGCTCTTTCCTCGTCAG & GTTGCAGTATTTGCAGTTGA \\
Slug & CTCTCCTCTTTCCGGATACT & AGCAGTTTTTGCACTGGTAT \\
Vimentin & GATGCTTCAGAGAGAGGAAG & CTCTTCGTGGAGTTTCTTCA \\
E-cadherin & CGAGAGCTACACGTTCAC & GGGAAAAATAGGCTGTCCTT \\
N-cadherin & CAACGACGGGTTAGTCAC & ATTGGGGTCTGGAGTTTC \\
Zeb-1 & CTTGTGATTTGTGTGACAAGA & ATGCCTTTTTACAGATTCCA \\
MMP-2 & TTTGATGACGATGAGCTATG & TGCAGCTCTCATATTTGTTG \\
MMP-3 & TCATTTTGGCCATCTCTTCC & GTGCCCATATTGTGCCTTCT \\
MMP-9 & AACTACGACCGGGACAAG & ATTCACGTCGTCCTTATGC \\
ERK1 & ACACGCAGTTGCAGTACA & CCACATACTCCGTCAGGA \\
ERK2 & CCAACCTCTCGTACATCG & GTCAGGAACCCTGTGTGA \\
c-Fos & CAGACTACGAGGCGTCATCC & TCTGCGGGTGAGTGGTAGTA \\
c-Jun & AAGATCCTGAAACAGAGCAT & GCTGGACTGGATTATCAGG \\
Cyclin D1 & CGGTGTCCTACTTCAAATGT & ACCTCCTCCTCCTCCTCT \\
Cyclin D2 & GGAGAAGCTGTCTCTGATCC & GGGTACATGGCAAACTTAAA \\
GAPDH & CGCTGCTTTTAACTCTGGTA & GACTGTGGTCAGAGTCCTT \\
GAPDH (qPCR) & CTGAGTACGTCGTCGTGGAGTC & ACTGAACCTGACCGTACACAGAGATGATGACCCTTTTG \\
Actin (qPCR) & GGACCTGACTGACTACCTCA & ACTGAACCTGACCGTACAAGCTTCTCCTTAATGTCACG \\
\hline
\end{tabular}

The underlined sequence in the reverse primers is the additional $\mathrm{Z}$ sequence which is complementary to the universal $\mathrm{Z}$ probe. $\mathrm{qPCR}$, quantitative polymerase chain reaction; Zeb-1, zinc finger E-box-binding homeobox 1; MMP, matrix metalloproteinase; ERK, extracellular signal-regulated kinase.

$95^{\circ} \mathrm{C}$ for $2 \mathrm{~min}$, followed by 40 cycles of $95^{\circ} \mathrm{C}$ for $30 \mathrm{sec}, 55^{\circ} \mathrm{C}$ for $30 \mathrm{sec}$ and $72^{\circ} \mathrm{C}$ for $30 \mathrm{sec}$, and a final extension of $5 \mathrm{~min}$ at $72^{\circ} \mathrm{C}$. The PCR products were visualized on $1-2 \%$ agarose gels stained with SYBR Safe (Invitrogen; Thermo Fisher Scientific, Inc., Waltham, MA, USA). The primer sequences used for PCR in this study are listed in Table II.

qPCR was run on the StepOne Plus Real-Time PCR system (Applied Biosystems; Thermo Fisher Scientific, Inc.), using Precision FAST 2X qPCR MasterMix (Primerdesign Ltd., Chandler's Ford, UK) in a final volume of $10 \mu \mathrm{l}$. cDNA samples from GC cells and two cohorts of GC tissues were examined for psoriasin transcript expression with standard and negative controls. Reaction conditions were as follows: $94^{\circ} \mathrm{C}$ for $10 \mathrm{~min}$, followed by 100 cycles of $94^{\circ} \mathrm{C}$ for $10 \mathrm{sec}, 55^{\circ} \mathrm{C}$ for $30 \mathrm{sec}$ and $72^{\circ} \mathrm{C}$ for $10 \mathrm{sec}$. GAPDH or actin was used as an internal control. The primer sequences used for qPCR are listed in Table II. Primers for qPCR were designed to the specific target using the Beacon Designer software (version 2; Premier Biosoft International, Palo Alto, CA, USA). An additional sequence, known as the $\mathrm{Z}$ sequence (5'-ACTGAACCTGACCGTACA-3'), which acts as a template for the amplifluor uniprimer probe, was added with the reverse primers. Expression of the target sequence was qualified in conjunction with a range of known dilution series of podoplanin gene transcript, which are used to generate a standard curve to enable the calculation of transcript copy.

Construction of psoriasin overexpression vector in GC cell lines. Full-length human psoriasin coding sequence was amplified from human prostate tissues with appropriate primers (Table I). The synthesized product was cloned into the pEF6/V5-His-TOPO plasmid vector (K961020; Invitrogen; Thermo Fisher Scientific, Inc.) according to the manufacturer's instructions. The overexpression constructs and control plasmids (25 $\mu \mathrm{g}$ pre transfection) were then transfected into $2.5 \times 10^{6}$ AGS and HGC-27 cells using a Gene Pulser Xcell electroporation system (Bio-Rad Laboratories, Inc., Hercules, CA, USA). After 2 weeks of selection using $6 \mu \mathrm{g} / \mathrm{ml}$ blasticidin (Melford Laboratories, Ltd., Ipswich, UK), stable transfectants were obtained and verified for psoriasin overexpression. Then cells were cultured in DMEM with a lower concentration of blasticidin $(0.6 \mu \mathrm{g} / \mathrm{ml})$ to maintain plasmid expression.

Treatment with ERK inhibitor and cisplatin. AGS and HGC-27 were cultured in serum-free medium for 4-6 h, and then treated with $1 \mu \mathrm{M}$ ERK inhibitor (FR 180204; Tocris Bioscience, Bristol, UK) or $16.6 \mu \mathrm{M}$ cisplatin (Tocris Bioscience) for $24 \mathrm{~h}$, followed by PCR, western blotting or flow cytometry analysis.

Western blotting. AGS and HGC-27 were isolated by pre-chilled lysis buffer (50 mM Tris- $\mathrm{Cl}, \mathrm{pH} 7.5,1 \%$ Nonidet P-40, $0.5 \%$ sodium deoxycholate, $0.05 \%$ SDS, $1 \mathrm{mM}$ EDTA, $150 \mathrm{mM}$ $\mathrm{NaCl}$ ) containing protease inhibitor cocktail (aprotinin and leupeptin) and phosphorylation inhibitor (sodium vanadate) and qualified with a DCTM protein assay kit (Bio-Rad Laboratories, Inc.). Protein extract of each sample $(30 \mu \mathrm{g})$ was separated by $10 \%$ or $12 \%$ SDS-PAGE and transferred onto a $0.45 \mu \mathrm{m}$ 
polyvinylidenedifluoride membrane (EMD Millipore, Billerica, MA, USA). The membranes were blocked with 5\% non-fat dried milk in PBST solution (0.05\% Tween-20 in PBS) for $1 \mathrm{~h}$ at room temperature. The blocked membranes were then incubated in a diluted primary antibodies (1:500) overnight as $4^{\circ} \mathrm{C}$, washed in PBST and incubated with a diluted specific horseradish peroxidase (HRP)-conjugated secondary antibody $(1: 2,000)$ for $1 \mathrm{~h}$ at room temperature. The following primary antibodies were used in the study: Anti-S100A7/psoriasin (clone 47C1068; catalog no.; Novus Biologicals, Ltd., Cambridge, UK); phospho (p)-ERK (Tyr 204; cat. no. sc-7976), ERK1/2 (clone C-9; cat. no. sc-514302), p21 (cat. no. sc-6246), p53 (clone DO-1; cat. no. sc-126), vimentin (cat. no. sc-66002), E-cadherin (cat. no. sc-1500), N-cadherin (cat. no. sc-7939), zinc finger E-box binding homeobox 1 (Zeb-1; cat. no. sc-81428) and GAPDH (cat. no. sc-32233; all Santa Cruz Biotechnology, Inc., Dallas, TX, USA). The HRP secondary antibodies (cat. no. A5278, anti-mouse IgG; cat. no. A0545, anti-rabbit IgG) were obtained from Sigma-Aldrich (Merck, KGaA). Detection was performed using an EZ-ECL chemiluminescence kit (Biological Industries USA, Inc., Cromwell, CT, USA). Immunoreactive bands were visualized and quantified by densitometry using the Syngene G:BOX chemiluminescence imaging system and Gene Tools 4.03 (Syngene Europe, Cambridge, UK).

Cell proliferation assay. Briefly, AGS and HGC-27 cells were seeded into 96 -well plate $\left(2 \times 10^{3}\right.$ cells/well $)$ in 6 replicates followed by incubation for $0,1,2,3,4$ and 5 days. Following fixation in $4 \%$ formalin for $30 \mathrm{~min}$ at room temperature, the cells were stained with $0.5 \%$ (w/v) crystal violet (Sigma-Aldrich) for $15 \mathrm{~min}$ at room temperature. Following washing, the cells were then extracted with $10 \%$ (v/v) acetic acid and cell density was determined by measuring the absorbance at $540 \mathrm{~nm}$ using a spectrophotometer (Elx800; BioTek Instruments, Inc., Winooski, VT, USA).

Cell viability assay. To evaluate the cytotoxicity of cisplatin, AGS and HGC-27 cells were plated into 96-well plate (cells/well) in 6 replicates. After 24-h incubation, the cells were exposed to serial concentrations of cisplatin $(0,3.125,6.25,12.5,25$ and $50 \mu \mathrm{M}$, respectively) for $72 \mathrm{~h}$. Cells viability was assessed by staining with $0.5 \%(\mathrm{w} / \mathrm{v})$ crystal violet for $15 \mathrm{~min}$ at room temperature.

Cell colony assay. AGS and HGC-27 were plated into 6-well plate at the density of 400 cells/ well and incubated at $37^{\circ} \mathrm{C}$ and at an atmosphere of $5 \% \mathrm{CO}_{2}$ for 2 weeks. The cell colonies were fixed in $4 \%$ formalin for $30 \mathrm{~min}$ and stained with $0.5 \%(\mathrm{w} / \mathrm{v})$ crystal violet for $15 \mathrm{~min}$. After images were taken with a camera, the colonies were dissolved in $10 \%$ (v/v) acetic acid, and the absorbance was measured at $540 \mathrm{~nm}$ using a spectrophotometer (Elx800; BioTek Instruments, Inc.).

Cell-matrix adhesion assay. A total of $2 \times 10^{4}$ cells were plated in each well of a black 96-well plate previously coated with Matrigel (10 $\mu \mathrm{g} /$ well; Corning Incorporated, Corning, NY, USA) in 6 replicates. After incubation for $1 \mathrm{~h}$, the cells were washed once with PBS and then incubated in cell dissociation solution (100 $\mu \mathrm{l} /$ well; Sigma-Aldrich; Merck KGaA) for $30 \mathrm{~min}$ containing $0.002 \mu \mathrm{g} / \mu \mathrm{l}$ calcein AM (eBioscience; Thermo Fisher Scientific, Inc.). Fluorescence of the cell suspension was read using a GloMax ${ }^{\circledR}$-Multi Detection System (Promega Corporation) at $495 \mathrm{~nm}$ for excitation and $519 \mathrm{~nm}$ for emission.

In vitro invasion assay. Cells $\left(5 \times 10^{4}\right)$ were loaded into an $8 \mu \mathrm{m}$-pore ThinCertTM 24-well plate insert (Greiner Bio-One International $\mathrm{GmbH}$, Kremsmünster, Austria) coated with $100 \mu \mathrm{g}$ Matrigel (each sample in triplicate). The upper chamber was provided with serum-free medium, and the lower chamber was filled with DMEM with 10\% FCS. Following incubation for $24 \mathrm{~h}$, the underside of the insert was incubated in $350 \mu \mathrm{l}$ dissociation solution containing $1 \mu \mathrm{M}$ calcein AM for $1 \mathrm{~h}$. The cell suspension was then aliquoted into a black 96-well plate $\left(100 \mu \mathrm{l} /\right.$ well) and read using the GloMax ${ }^{\circledR}$-Multi Detection System at $495 \mathrm{~nm}$ for excitation and $519 \mathrm{~nm}$ for emission.

In vitro cell migration assay and the effect of ERK inhibitor on cell mobility. Electric cell-substrate impedance sensing (ECIS) instruments (Applied Biophysics, Inc., Troy, NY, USA) were used to monitor cell migration by detecting impedance variation based on the current flow change on the gold electrodes of a 96-well array (Applied Biophysics Inc.) (22). There are two parameters, resistance and capacitance, derived from current and voltage measurements. Among them, resistance, consisting of para- and trans-cellular current flow, is better to represent the quality and function of cell barrier (23). Briefly, $6 \times 10^{4}$ cells diluted in $200 \mu \mathrm{l}$ DMEM with or without ERK inhibitor $(1 \mu \mathrm{M})$ were seeded into each ECIS 96-plate well, and the cells were wounded by applying electric current $(3,000 \mu \mathrm{A}$, $60 \mathrm{kHz}$ ) when confluent monolayers were formed. The array was placed into a $\mathrm{CO}_{2}$ incubator, which was connected to the ECIS Model 9600 Controller, and the impedance data, which indicate cellular migration, were collected continuously for $6 \mathrm{~h}$. In this study, the normalized resistance measured at $4,000 \mathrm{~Hz}$ was chosen to evaluate cell function due to its high sensitivity to the current flow variation caused by the change of cell behavior as described in the literature (24).

Flow cytometric analysis. For protein expression analysis, AGS and HGC-27 were fixed with IC Fixation Buffer (eBioscience; Thermo Fisher Scientific, Inc.) at room temperature for $30 \mathrm{~min}$, and then permeabilized in ice-cold $100 \%$ methanol at $4^{\circ} \mathrm{C}$ for $30 \mathrm{~min}$. Following blocking with PBS containing $0.1 \%$ Tween-20 (v/v) and $1 \%$ bovine serum albumin (w/v) (Sigma-Aldrich; Merck KGaA), the cells were incubated with a cleaved poly(ADP-ribose) polymerase 1 (PARP1) antibody (1:40; cat. no. 44-698G; eBioscience; Thermo Fisher Scientific, Inc.) overnight at $4^{\circ} \mathrm{C}$. Mouse IgG2b K isotype antibody (eBioscience; Thermo Fisher Scientific, Inc.) was used as a control. The samples were then washed by PBS twice and resuspended in PBS containing 2 mM EDTA and 5\% FCS for flow cytometry.

For cell cycle analysis, the cells were fixed with $70 \%$ ethanol for 15 min on ice, and stained with FxCycle ${ }^{\mathrm{TM}}$ PI/RNase staining solution (Thermo Fisher Scientific, Inc.) for $30 \mathrm{~min}$. For apoptosis analysis, the cells were stained using an Annexin V Apoptosis Detection kit (eBioscience; Thermo Fisher Scientific, Inc.) following the manufacturer's instructions. Flow cytometry was performed using a Canto II flow cytometer (BD Bioscience, San Jose, CA, USA), and the data were analyzed using FCS Express version 4 Research Edition (De Novo Software, Glendale, CA, USA). 


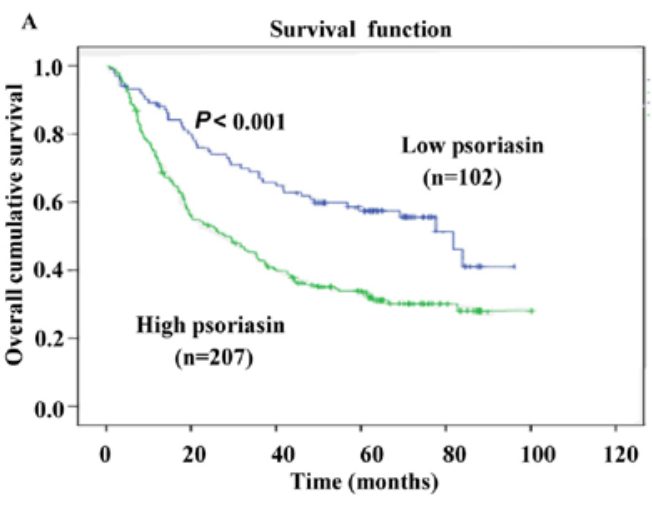

C
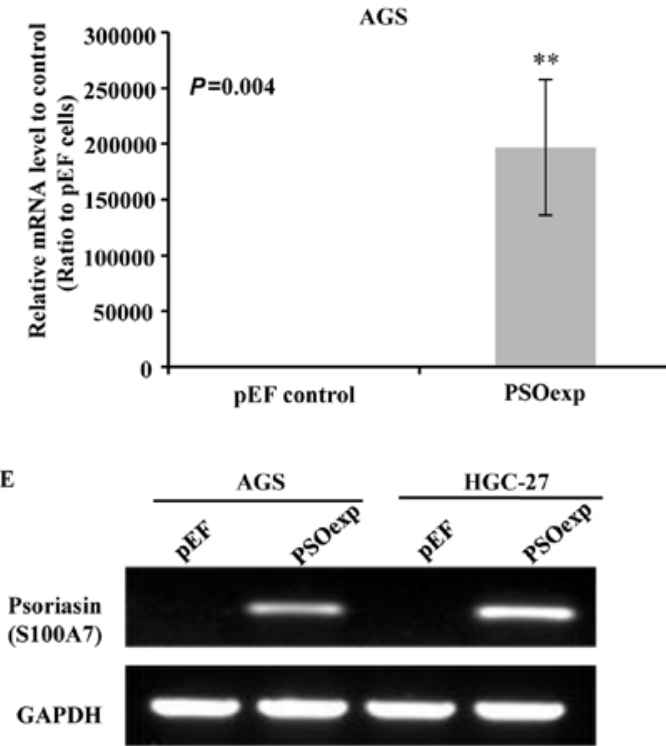

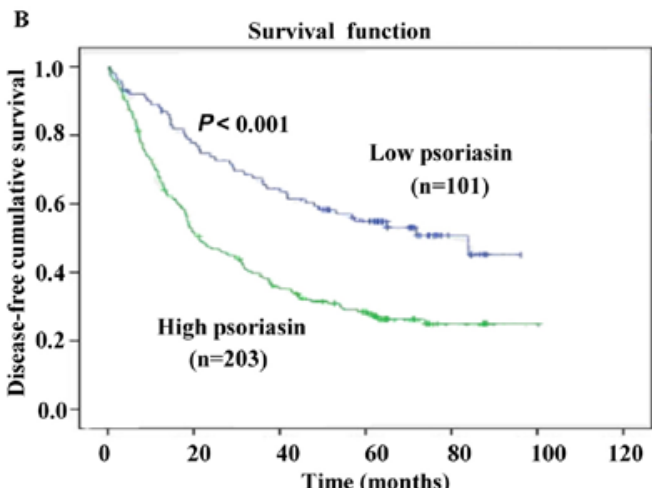

D

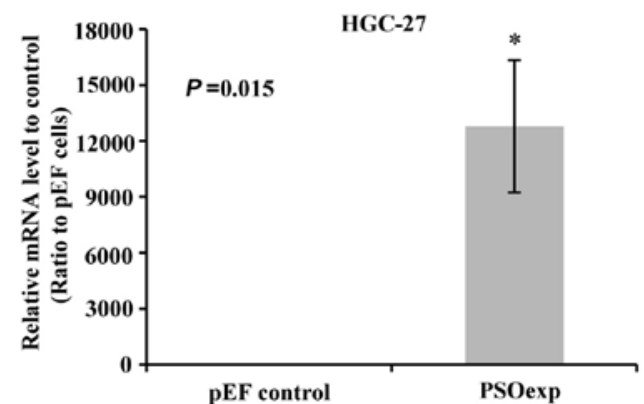

F
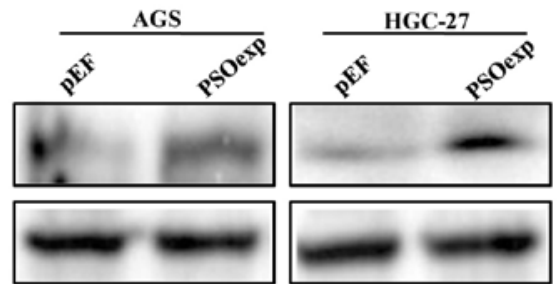

Figure 1. Survival curves of patients with GC, and the validation of psoriasin overexpression in GC cell lines. The high-low groups of patients were divided the median transcript values of psoriasin, guided by clinical stages (TNM staging). (A) Association between the transcript levels of psoriasin and overall survival. Low psoriasin group (median expression, 1), $\mathrm{n}=102$; high psoriasin expression (median expression, 25), $\mathrm{n}=207, \mathrm{P}<0.001$. $(\mathrm{B}) \mathrm{The}$ correlation between the transcript levels of psoriasin and disease-free survival. Low psoriasin group (median expression, 1), $\mathrm{n}=101$; high psoriasin expression (median expression, 25), $\mathrm{n}=203$. $\mathrm{P}<0.001$. Reverse transcription-quantitative PCR analyzing mRNA expression of psoriasin in (C) AGS and (D) HGC-27 cell line, which was normalized with the reference gene GAPDH. The data are presented as a ratio to pEF control. (E) Confirmation of psoriasin overexpression in AGS and HGC-27 cells using conventional PCR. (F) Western blot analysis of the level of psoriasin expression in AGS and HGC-27 cell lines using an anti-S100A7/psoriasin antibody (clone $47 \mathrm{C} 1068$ ). ${ }^{*} \mathrm{P}<0.05,{ }^{* *} \mathrm{P}<0.01$ vs. pEF control. PCR, polymerase chain reaction; pEF, cells transfected with the empty plasmid vector; PSOexp, cells transfected with psoriasin plasmid.

Statistical analysis. The results are presented as data from three independent experiments and expressed as the mean \pm standard deviation. The cumulative survival curves were generated using Kaplan-Meier plots and analyzed using log-rank test. Kruskal-Wallis test was used for comparisons of three or more groups followed by Tukey Honest Significant Difference as a post hoc test, and Mann-Whitney U test was used for comparisons between two groups. Statistical analysis was performed using SPSS v18 (SPSS, Inc., Chicago, IL, USA) and GraphPad Prism 6.0 (GraphPad Software, La Jolla, CA, USA). P<0.05 was considered to indicate a statistically significant difference.

\section{Results}

Expression of psoriasin transcripts and its correlation with clinicopathological parameters in GC tissues. To determine the clinical relevance of psoriasin in GC progression, the transcript levels of psoriasin in GC $(n=321)$ and the adjacent normal specimens $(n=173)$ were examined by RT-qPCR. As presented in in
Table II, psoriasin was higher in GC tissues than in adjacent normal tissues $(\mathrm{P}<0.001)$, and a higher level of psoriasin was observed in advanced stages of GC (TNM III+IV) compared with early stages (TNM I+II; P<0.001; Table II). Notably, higher expression of psoriasin was detected in tumors with deeper infiltration (T3-4 vs. T1-2; $\mathrm{P}=0.011)$, lymph node involvement $(\mathrm{P}<0.001)$ and distance metastasis $(\mathrm{P}<0.001$, Table II $)$. Furthermore, psoriasin exhibited higher expression in patients with GC that had died prior to the end of follow-up than in those who remained alive at the end of the follow-up period $(\mathrm{P}<0.001$; Table II). Kaplan-Meier analysis and log-rank test revealed that patients with GC with higher expression of psoriasin had worse overall survival $(\mathrm{P}<0.001$; Fig. $1 \mathrm{~A})$ and disease-free survival $(\mathrm{P}<0.001$; Fig. 1B), compared with those with lower expression.

Psoriasin overexpression promotes cell proliferation, invasion and migration in AGS and HGC-27, and decreases adhesion in HGC-27 cells. AGS and HGC27 are two well-characterized gastric cancer cell lines $(25,26)$. As demonstrated in Fig. 1, 
A

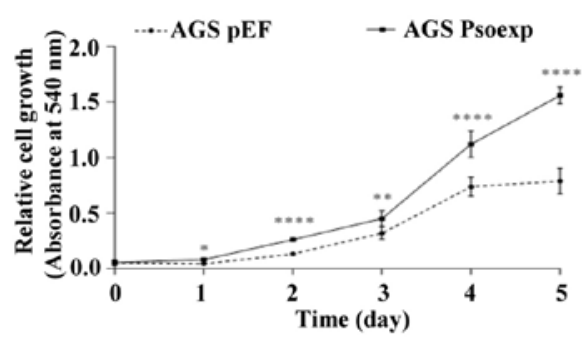

C

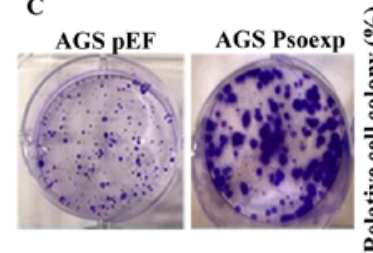

E

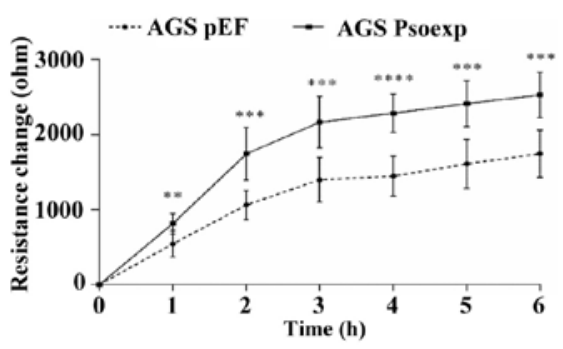

B

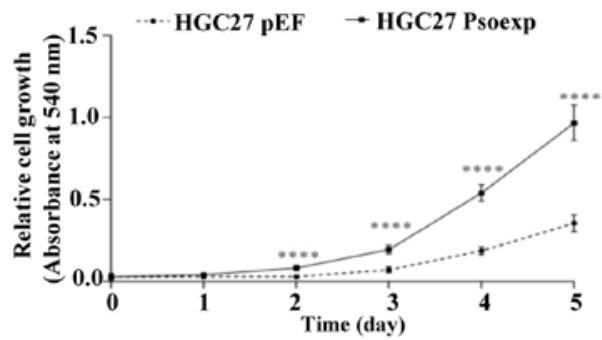

D

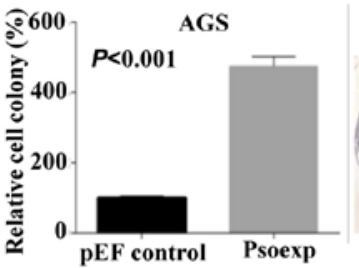

F
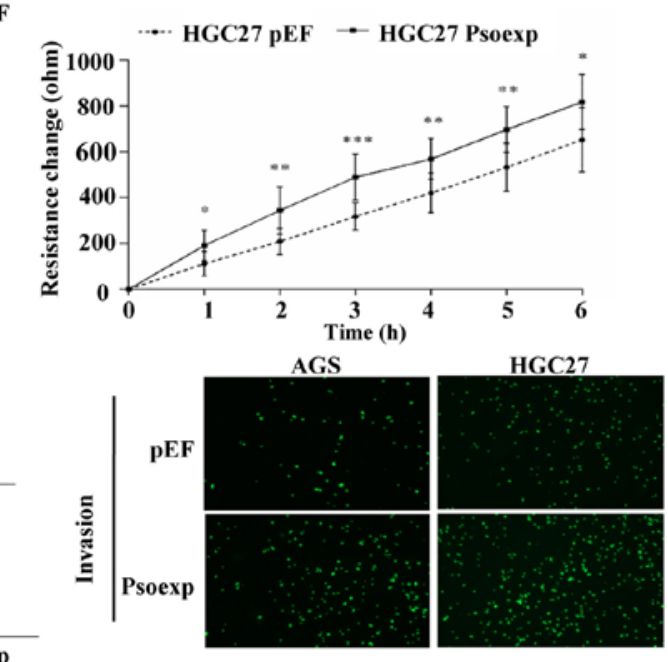

AGS

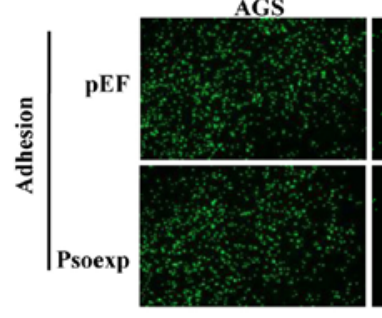

HGC27
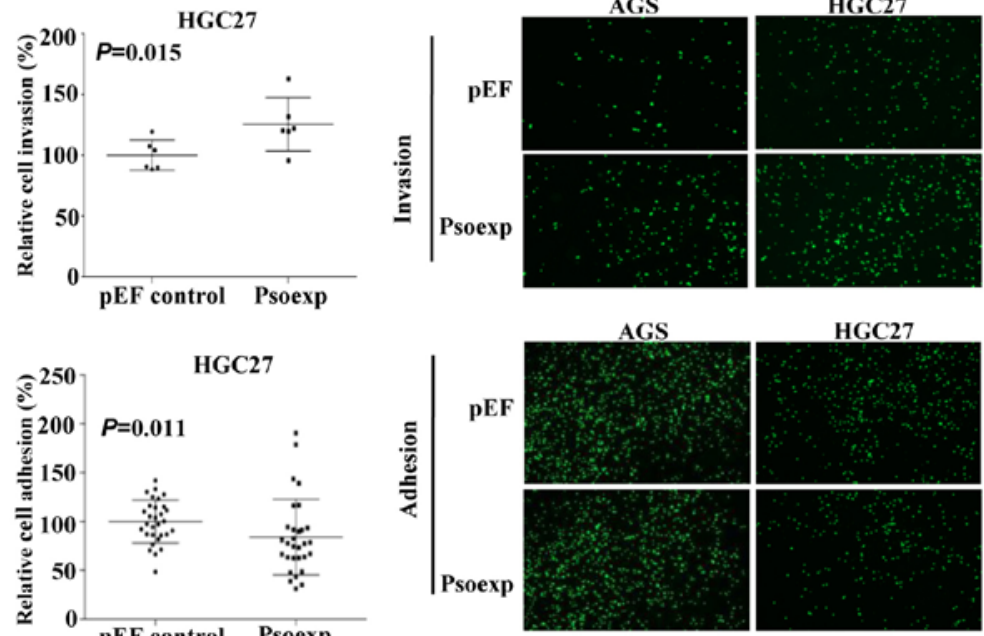

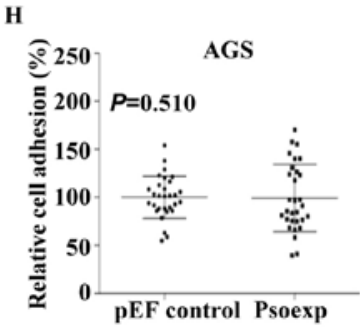

Figure 2. Effect of psoriasin overexpression on the functions of AGS and HGC-27 cell lines in vitro. (A) Growth of cells that overexpress psoriasin (AGS PSOexp) compared with its control (AGS pEF). (B) Growth of cells that overexpress psoriasin (HGC-27 PSOexp) compared with its control (HGC-27 pEF). (C) Colonyformation ability in AGS cells following psoriasin upregulation. (D) Increase in colony-formation ability in HGC-27 cell following psoriasin upregulation. Migration of (E) AGS and (F) HGC-27 cells determined by the ECIS system. Data are presents as resistance change (ohm). Higher values are proportional to higher levels of migration ability. ${ }^{*} \mathrm{P}<0.05,{ }^{* *} \mathrm{P}<0.01,{ }^{* * * *} \mathrm{P}<0.001,{ }^{* * * * *} \mathrm{P}<0.0001$ vs. pEF. (G) Representative images of the invaded cells in chambers following incubation for $24 \mathrm{~h}$ and staining with calcein AM (right panel) and quantitative analysis of invasive cells (left panel). The density of green cells indicated the levels of invasion from different cell groups. (H) Representative images of adhesive cells after incubation on Matrigel for $1 \mathrm{~h}$ and stained with calcein AM (right) with corresponding quantitative analysis of adhesive cells (left). The density of green cells indicated the levels of adhesion from different cell groups. Data are presented as the mean \pm standard deviation. pEF, cells transfected with the empty plasmid vector; PSOexp, cells transfected with psoriasin plasmid.

the gene expression of psoriasin is low in these two GC cell lines, as indicated by RT-qPCR (Fig. 1C and D) and conventional PCR (Fig. 1E). Western blotting also demonstrated that the protein levels of psoriasin in AGS and HGC27 were low (Fig. 1F). Attempts were made to subculture other GC cell lines, such as NUGC-1, MKN-45, MKN7 and MKN74. Unfortunately, they were either floating (NUGC-1, MKN-45) or was difficult expand during the establishment of the stable cells lines (MKN7 and MKN74). Therefore, AGS and HGC-27 were to establish stable psoriasin-overexpressed cell lines
(AGS PSOexp and HGC-27 PSOexp) to determine the role of psoriasin in the tumorigenesis and progression of GC. The mRNA and protein levels of psoriasin was markedly increased in AGS PSOexp and HGC-27 PSOexp cells compared with the cells that were transfected with the vector alone (AGS pEF and HGC-27 pEF) as verified by RT-qPCR (Fig. 1C and D), PCR (Fig. 1E) and western blotting (Fig. 1F).

There was a significant increase in cell proliferation in psoriasin-overexpressed cells compared with the controls, which was assessed by crystal violet assay $(\mathrm{P}<0.001$; Fig. $2 \mathrm{~A}$ 
A
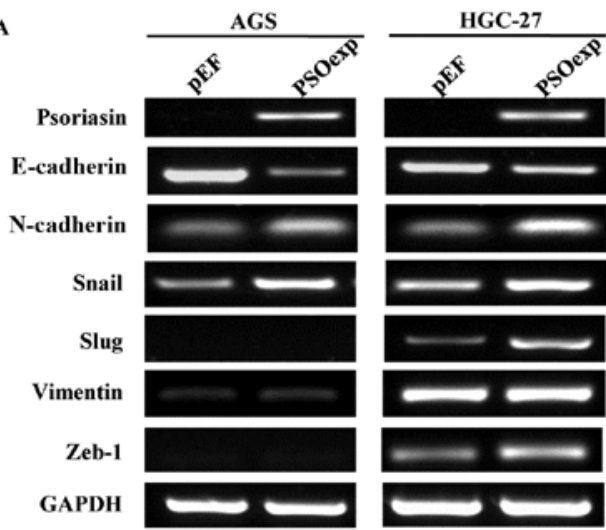

C

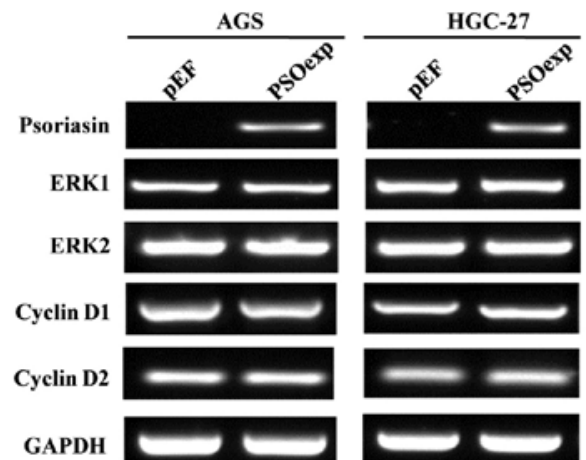

E

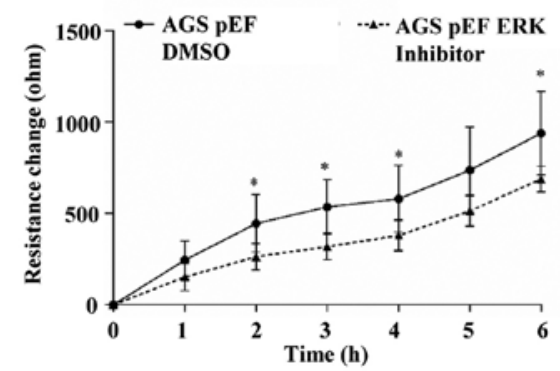

B

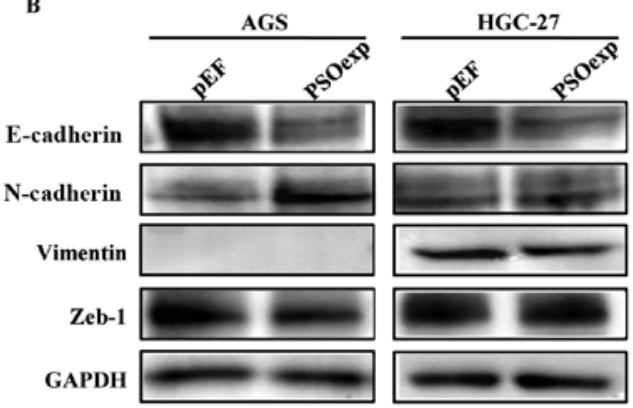

D
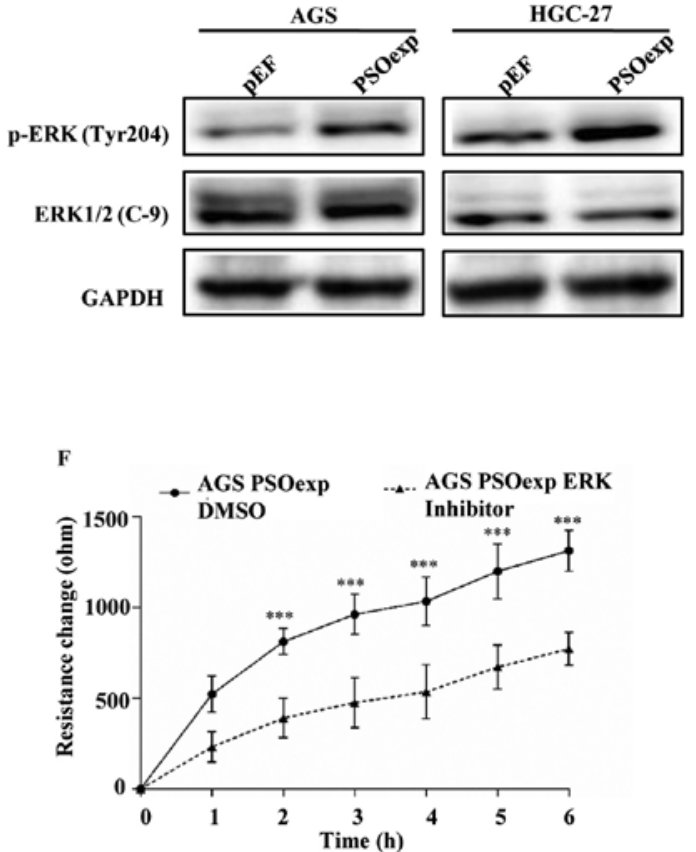

Figure 3. Effect of psoriasin overexpression on EMT and ERK expression in the gastric cancer cell lines, and effect of psoriasin on the motility and ERK expression in AGS cells that were treated with an ERK inhibitor. (A) Expression profiles of EMT in response to psoriasin overexpression in AGS and HGC-27 cells as evaluated by PCR. (B) Expression profiles of EMT in response to psoriasin overexpression in AGS and HGC-27 cells as evaluated by western blotting. (C) Evaluation of ERK activity in AGS and HGC-27 cells by PCR. (D) Evaluation of ERK activity in AGS and HGC-27 cells by western blotting. Electric cell-substrate impedance sensing analysis demonstrating migration of (E) AGS pEF and (F) AGS PSOexp cells following treatment with $1 \mu$ M ERK inhibitor. Data are presented as the mean \pm standard deviation. EMT, epithelial-mesenchymal transition; PCR, polymerase chain reaction; pEF, cells transfected with the empty plasmid vector; PSOexp, cells transfected with psoriasin plasmid; Zeb-1, zinc finger E-box-binding homeobox 1; ERK, extracellular signal-regulated kinase; p-, phospho-; DMSO, dimethyl sulfoxide.

and B). Similarly, cell colony formation was also enhanced in the psoriasin-overexpressed cells (Fig. 2C and D). However, there was no effect on the cell cycle profile following psoriasin overexpression (data not shown).

As psoriasin expression was positively associated with lymph node involvement and distant metastasis (Table II), the migratory and invasive abilities of GC cells were evaluated in vitro. The Matrigel invasion assay and ECIS assay demonstrated that the overexpression of psoriasin dramatically enhanced migration (Fig. 2E and F) and invasion (Fig. 2G) in GC cell lines compared with the vector controls. Furthermore, upregulation of psoriasin significantly decreased cell-matrix adhesion in HGC-27 cells, but not in AGS cells (Fig. 2H). Together, these data suggest that psoriasin may function as an inducer of cell migration and invasion in GC.
Expression of epithelial-mesenchymal transition (EMT) markers in GC cells. Several EMT-associated molecules have been implicated in the development and progression of GC by altering the malignant properties of cancer cells $(14,27)$. Therefore, the expression of epithelial markers, mesenchymal markers and EMT transcription factors were evaluated following overexpression of psoriasin by PCR and western blotting. The results demonstrated that the levels of $\mathrm{N}$-cadherin and Snail expression were increased, while E-cadherin expression was decreased in AGS PSOexp and HGC-27 PSOexp cells compared with the empty vector controls. In addition, the upregulation of psoriasin promoted Slug and Zeb-1 expression levels in HGC-27 cells compared with the control cells, whereas the vimentin level was unchanged in both cell lines (Fig. 3A and B). Collectively, the activation of psoriasin may 
Table III. Quantitative gene expression analysis of psoriasin in patients with gastric cancer receiving chemotherapy.

\begin{tabular}{|c|c|c|c|}
\hline Variable & $\mathrm{n}$ & $\begin{array}{l}\text { Psoriasin } \\
\text { expression } \\
\text { (median) }\end{array}$ & P-value \\
\hline Tissue & & & 0.005 \\
\hline Tumor & 87 & 0.40 & \\
\hline Adjacent normal & 83 & 1.09 & \\
\hline Sex & & & 0.816 \\
\hline Male & 63 & 0.41 & \\
\hline Female & 24 & 0.33 & \\
\hline \multicolumn{4}{|l|}{ Differentiation } \\
\hline Differentiated & 20 & 0.53 & \\
\hline Undifferentiated & 59 & 0.41 & $0.500^{\mathrm{a}}$ \\
\hline Others & 8 & 0.24 & $0.102^{\mathrm{a}}$ \\
\hline Tumor size (mm) & & & 0.202 \\
\hline$>50$ & 9 & 0.41 & \\
\hline$<50$ & 78 & 0.29 & \\
\hline Depth of invasion & & & 0.116 \\
\hline $\mathrm{T} 1-2$ & 9 & 0.19 & \\
\hline $\mathrm{T} 3-4$ & 78 & 0.41 & \\
\hline Lymph node status & & & 0.891 \\
\hline Negative & 16 & 0.34 & \\
\hline Positive & 71 & 0.41 & \\
\hline TNM staging & & & 0.113 \\
\hline $\mathrm{I}+\mathrm{II}$ & 9 & 0.34 & \\
\hline III+IV & 78 & 0.48 & \\
\hline $\begin{array}{l}\text { Response to neoadj } \\
\text { chemotherapy }\end{array}$ & & & 0.023 \\
\hline Response & 30 & 0.24 & \\
\hline No response & 57 & 0.50 & \\
\hline
\end{tabular}

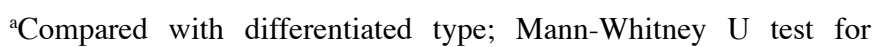
comparisons between two groups; Kruskal-Wallis test for multiple group followed Tukey honest significant difference as post hoc test. TNM, tumor-node-metastasis.

alter the patterns of EMT in GC cells, promoting cell invasion and migration.

Psoriasin enhances cell migration via activating ERK signaling in GC cells. The ERK signaling cascade is one of the key signaling pathways that regulates cell proliferation, invasion and migration by controlling multiple nuclear and cytoplasmic targets in cancer (28). In the present study, the effect of psoriasin on the ERK signaling pathway was investigated in GC. The upregulation of psoriasin significantly promoted the level of phosphorylated ERK (Tyr 204) protein, without altering the total ERK1/2 mRNA and protein levels in AGS and HGC-27 cells, compared with the control cells (Fig. 3C and D).

By contrast, there was no difference in the levels of cyclin D1 and cyclin D2 mRNA between the control cells and the cells that overexpressed psoriasin (Fig. 3C). Therefore, the effect of psoriasin on the viability of GC cells was unlikely due to the regulation of these regulatory proteins of cyclin-dependent kinases.

Treatment with an ATP-competitive ERK inhibitor suppressed the migratory ability of AGS cells (PSOexp cells and control cells), particularly in AGS PSOexp cells (Fig. 3E and F). Together, these results suggest that psoriasin may enhance cell migration at least partially via activation of ERK. Further study is required to determine whether ERK is a direct substrate of psoriasin.

Psoriasin overexpression increases resistance to cisplatin in GC cells. To determine the effect of psoriasin on cisplatin resistance in GC, the gene expression of psoriasin was analyzed in specimens from patients with GC that received pre-operative chemotherapy $(n=87)$. The results indicated that levels of psoriasin expression were higher in patients that exhibited no response to neoadjuvant chemotherapy $(\mathrm{P}=0.023$; Table III). Flow cytometry analysis of cleaved PARP was performed to evaluate the levels of apoptosis in the stable cell lines that were treated with cisplatin. As presented in Fig. 4A and B, in the presence of cisplatin, the less AGS PSOexp cells expressed cleaved PARP protein $(8.95 \%)$ than the AGS pEF cells (16.87\%), suggesting an increase in resistance to cisplatin. However, such increase was not observed in HGC-27 cells, as the cleaved PARP expression was not markedly altered between the HGC-27 PSOexp cell line (63.03\%) and the HGC-27 pEF cell line (59.38\%; Fig. 4A and B). The cell cycle analysis indicated that in response to the cisplatin treatment, a higher portion of AGS cells was arrested in the G2/M phase compared with PBS treatment in AGS pEF cells (58.68\% vs. 22.51\%) and AGS PSOexp cells (61.04\% vs. $23.55 \%$ ). However, there was no difference in cell cycle profile between the AGS PSOexp and AGS pEF cell lines in the presence of cisplatin. By contrast, the S-phase population of the HGC-27 PSOexp cells was increased compared with the pEF control cells in the presence of cisplatin $(44.68 \%$ in HGC-27 pEF cells and 60.84\% in HGC-27 PSOexp cells; Fig. 4C-F). Furthermore, psoriasin overexpression in AGS cells inhibited the cisplatin-induced increase in the levels of p53 and p21 proteins compared with the cells transfected with the backbone pEF plasmid (Fig. 4G and H). However, the cell viability assay showed that although psoriasin overexpression improved survival rates in the presence of particular doses of cisplatin (e.g. $6.25 \mu \mathrm{M}$ ) in transfected AGS and HGC-27 cells compared with the pEF controls $(\mathrm{P}<0.05)$, the overall dosedependent cytotoxic effect of cisplatin on the cell lines was similar to the control cell lines (data not shown). Therefore, the upregulation of psoriasin in GC cells may desensitize cells to cisplatin by promoting the proportion of cells in the S-phase or inhibiting apoptosis, instead of a direct effect via cellular cytotoxicity.

\section{Discussion}

Psoriasin is dysregulated in multiple solid tumors and performs multiple roles in a variety of pathophysiological processes, which are closely associated with tumorigenesis and cancer progression. However, knowledge on the 


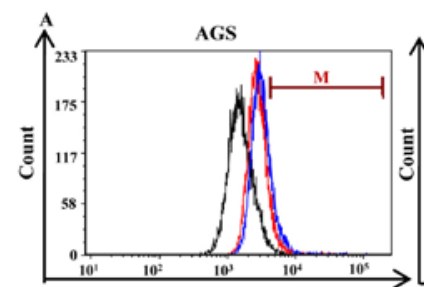

Cleaved PARP (PE-A)

C

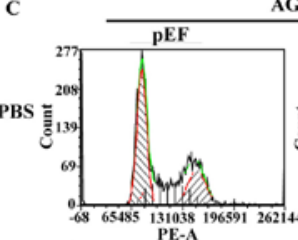

AGS
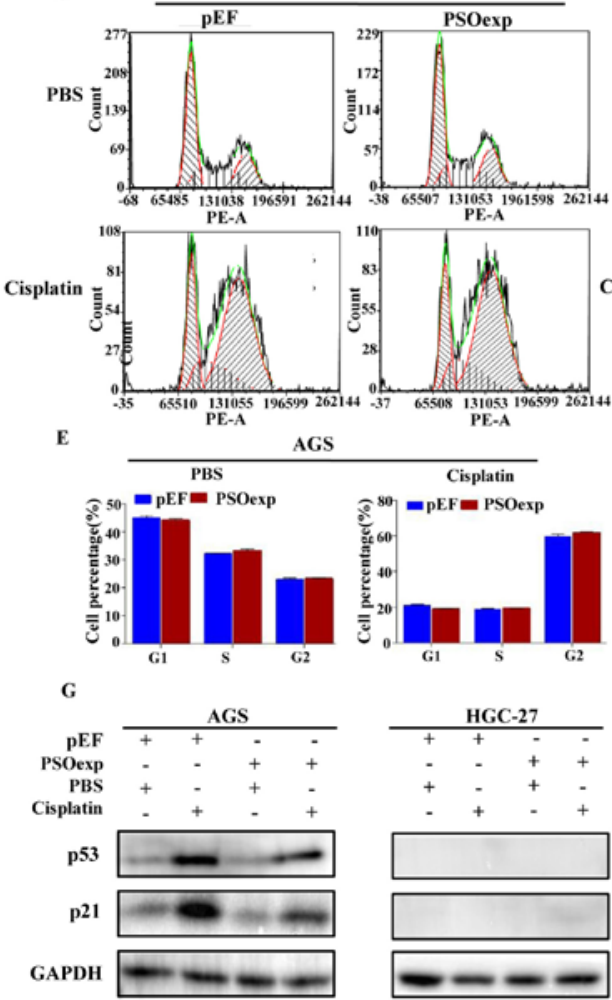

D

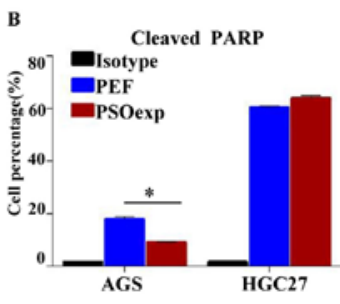

HGC-27
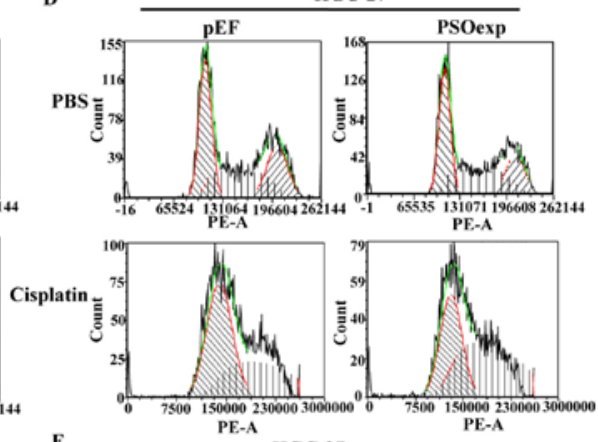

F
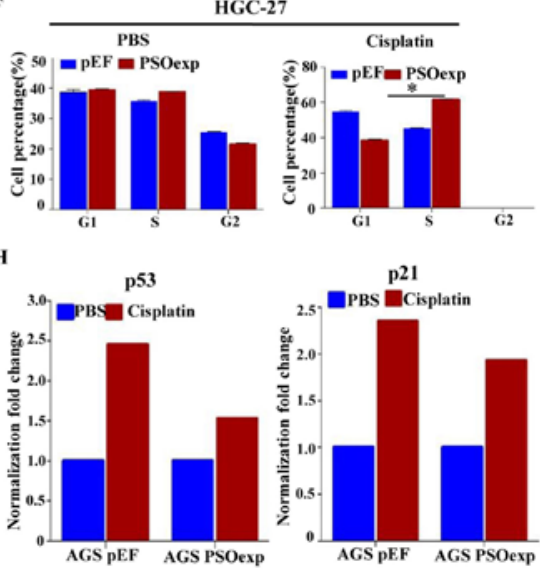

Figure 4. Effect of psoriasin overexpression on resistance to cisplatin in gastric cancer cells. (A) Flow cytometry analysis of the cleaved PARP levels in AGS and HGC-27 cells in response to treatment with $16.6 \mu \mathrm{M}$ cisplatin for $24 \mathrm{~h}$. Black line, isotype; red line, pEF cells; blue line, PSOexp cells. (B) Cell percentage in cleaved PARP protein production in AGS and HGC27 cell lines in treatment with cisplatin by flow cytometry. (C) Changes in AGS cells (pEF and PSOexp) cycle profile following treatment with $16.6 \mu \mathrm{M}$ cisplatin for $24 \mathrm{~h}$. (D) Changes in HGC-27 cells (pEF and PSOexp) cycle profile following treatment with $16.6 \mu \mathrm{M}$ cisplatin for $24 \mathrm{~h}$. (E) Histogram of AGS cell cycle distribution. (F) Histogram of HGC-27 cell cycle distribution. (G) Levels of p21 and p53 proteins in AGS and HGC-27 cell lines that were treated with cisplatin as indicated by western blotting. (I) Fold change in p21 and p53 protein production in AGS cells in response to cisplatin as indicated by densitometric quantification of western blotting. The data from western blotting analysis were normalized using GAPDH. Data are presented as the mean \pm standard deviation. ${ }^{*} \mathrm{P}<0.05$ vs. relevant controls. PARP, poly(ADP-ribose) polymerase; $\mathrm{pEF}$, cells transfected with the empty plasmid vector; PSOexp, cells transfected with psoriasin plasmid; PBS, phosphate-buffered saline.

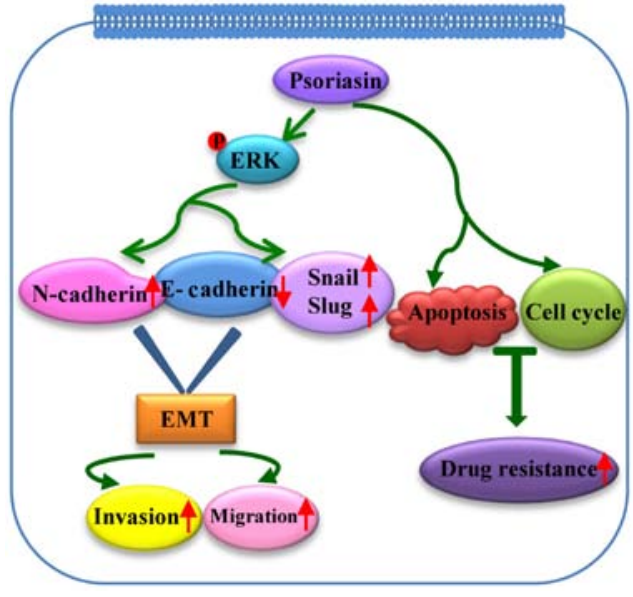

Figure 5. Schematic illustration of the potential roles of psoriasin in gastric cancer cells. p-, phospho-; ERK, extracellular signal-regulated kinase; EMT, epithelial-mesenchymal transition. expression patterns and biological function of psoriasin in the progression of GC remains limited. In the present study, there was an increased level of psoriasin mRNA expression in GC tissues compared with adjacent normal tissues. Furthermore, this increase in psoriasin expression was also associated with lymph node involvement in patients, distant metastasis and advanced stages of the disease. These findings are consistent with the previous studies on cervical cancer and breast cancer $(18,29)$. Additionally, Kaplan-Meier plot analysis indicated that higher psoriasin expression led to worse overall survival and disease-free survival, which was supported by the outcomes of meta-analysis from the KaplanMeier Plotter (gastric cancer) database (http://kmplot.com/ analysis; data not shown). The association between psoriasin expression and clinicopathological characteristics indicates that psoriasin has a role in the development and progression of GC. 
To further clarify the roles of psoriasin in gastric carcinogenesis and progression, the effects of upregulating psoriasin on cell function were evaluated. In this study, overexpression of psoriasin in AGS and HGC-27 GC cell lines promoted cell proliferation, migration and invasion, and inhibited adhesion in the HGC-27 cell line. A recent study reported that psoriasin may promote cyclin activation and cell cycle progression in pancreatic cancer cells (30). However, in the present study psoriasin had no effect on cell cycle distribution and gene expression of cell cycle regulators.

EMT is a biological process that allows polarized epithelial cells to undergo multiple changes in order to acquire a mesenchymal cell phenotype, therefore enhancing cell migration, invasion and metastasis (31). Loss of E-cadherin and increased expression of $\mathrm{N}$-cadherin are hallmarks of EMT, which promote the interaction of the cell with endothelial and stromal components $(27,32,33)$. Notably, the present data demonstrated that psoriasin drives the upregulation of $\mathrm{N}$-cadherin, Snail, Slug and Zeb-1 expression and loss of E-cadherin expression in GC cells. Snail, Slug and Zeb-1, which are important transcription factors, trigger EMT by coordinating the induction of mesenchymal biomarkers and the repression of epithelial biomarkers (27). Collectively, these results suggest that psoriasin may be a potent inducer of EMT, which regulates cell invasion and migration in GC. However, the precise mechanism by which this occurs in GC requires further investigation.

ERK signaling, one of the most important intracellular pathways, has multiple functions in cancer cells, including roles in proliferation, cell cycle, EMT, migration, invasion, repression of apoptosis and induction of drug resistance (34-36). In the present study, migration was notably increased by ERK activation induced by psoriasin overexpression. Furthermore, the migration of AGS cells induced by psoriasin overexpression was inhibited by treatment with ERK inhibitor. Therefore, psoriasin may promote EMT by activating the ERK pathway, leading to enhanced migration and invasion of GC cells. However, the specific mechanism by which psoriasin affects cell migration and invasion requires further investigation.

Clinical data indicated that patients that positively responded to pre-operative chemotherapy had a significantly longer survival time than non-responders (5). Many studies have reported that the $\mathrm{S} 100$ proteins have the ability to regulate the sensitivity of tumor cells to chemotherapeutics (37-39). For instance, S100A11 sensitizes cells to cisplatin treatment in non-small cell lung cancer (40). However, to date, there has been no investigation into the association between psoriasin expression and chemotherapy resistance in tumors. To the best of our knowledge, the present study was the first to observe that elevated psoriasin expression in patients with GC was significantly associated with a poor pathological response to chemotherapy, suggesting that psoriasin might confer resistance in GC to chemotherapeutic drugs. In vitro experiments demonstrated that cells with a higher level of psoriasin expression exhibited less sensitivity to cisplatin compared with the control cells. The molecular basis of resistance to chemotherapy is generally complex, involving multiple processes, including drug metabolism and transport, apoptosis and DNA repair (41). In order to investigate the underlying mechanism, the expression cleaved PARP was used as an indicator of apoptosis and the cell cycle following treatment of cells with cisplatin. Based on the results, psoriasin may inhibit the sensitivity of GC cells to cisplatin by ameliorating cell apoptosis or inducing the S-phase arrest, depending on the molecular phenotype, epigenetic and genetic features or p53 status of the cells.

However, there were certain limitations of the present study. As AGS and HGC-27 cells were available, they were used to explore the effect of psoriasin overexpression in GC cells. It may be ideal to find a $\mathrm{GC}$ cell line that overexpresses S100A7 and possesses the phenotype of GC, and explore the further biological functions via psoriasin knockdown. In addition, as AGS and HGC27 cells have low tumor formation ability in mice, this study presented the role of psoriasin in GC cells via in vitro experiments only. In the future, another GC cell line should be used to determine the role of psoriasin in vivo.

In summary, to our best knowledge, this is the first report describing the role of psoriasin in GC and chemotherapy resistance in human tumors. Psoriasin expression is frequently increased in human GC cell lines and GC tissues, and its expression is associated with metastasis and a poor survival in patients with GC. Psoriasin overexpression in GC cells increased cell proliferation, migration and invasion. Furthermore, the promoting effects of psoriasin are potentially attributed to a positive effect on EMT-associated pathways via activation of ERK signaling (Fig. 5). As psoriasin overexpression leads to a higher tolerance to cisplatin in GC cells, patient with GC with a high level of psoriasin may be less sensitive to cisplatin. Therefore, the findings suggest that psoriasin has the potential as a therapeutic target in GC and may be a useful prognostic factor to predict the effectiveness of pre-operative chemotherapy in patients with GC.

\section{Acknowledgements}

The authors would like to thank Mrs. Fiona Ruge (Cardiff University, Cardiff, UK) for her technical assistance.

\section{Funding}

This work was supported by Beijing Municipal Administration of Hospitals Clinical Medicine Development of Special Funding Support (grant no. ZYLX201701), China Scholarship Council, and Cardiff China Medical Research Collaborative and Cancer Research Wales.

\section{Availability of data and materials}

The analysed datasets generated during the study are available from the corresponding author on reasonable request.

\section{Authors' contributions}

LL conducted most of the experiments in this study with some assistance from YC, LY, ZZ and WJ. JJ examined the gastric cancer tissues. WJ analysed the cohort gene expression data. YC carried out flow cytometry-based apoptosis and cell cycle analysis. LL, YC, LY and WJ provided helpful discussions and critically reviewed the manuscript. WJ and YC designed and 
conceived the study. LL and YC analysed all the data and wrote the manuscript. All authors commented on and approved the manuscript.

\section{Ethics approval and consent to participate}

This study was approved by Peking University Cancer Hospital Research Ethics Committee (ethics no. 2006021) and written consent was obtained from all patients involved.

\section{Patient consent for publication}

Not applicable.

\section{Competing interests}

The authors declare that they have no competing interests.

\section{References}

1. Torre LA, Bray F, Siegel RL, Ferlay J, Lortet-Tieulent J and Jemal A: Global cancer statistics, 2012. CA Cancer J Clin 65: 87-108, 2015

2. Van Cutsem E, Sagaert X, Topal B, Haustermans K and Prenen H: Gastric cancer. Lancet 388: 2654-2664, 2016.

3. Kanat O and O'Neil BH: Metastatic gastric cancer treatment: A little slow but worthy progress. Med Oncol 30: 464, 2013.

4. Ohtsu A: Chemotherapy for metastatic gastric cancer: Past, present, and future. J Gastroenterol 43: 256-264, 2008.

5. Cunningham D, Allum WH, Stenning SP, Thompson JN, Van de Velde CJ, Nicolson M, Scarffe JH, Lofts FJ, Falk SJ, Iveson TJ, et al; MAGIC Trial Participants: Perioperative chemotherapy versus surgery alone for resectable gastroesophageal cancer. N Engl J Med 355: 11-20, 2006.

6. Lee JH, Kim KM, Cheong JH and Noh SH: Current management and future strategies of gastric cancer. Yonsei Med J 53: 248-257, 2012.

7. Madsen P, Rasmussen HH, Leffers H, Honoré B, Dejgaard K, Olsen E, Kiil J, Walbum E, Andersen AH, Basse B, et al: Molecular cloning, occurrence, and expression of a novel partially secreted protein 'psoriasin' that is highly up-regulated in psoriatic skin. J Invest Dermatol 97: 701-712, 1991.

8. Watson PH, Leygue ER and Murphy LC: Psoriasin (S100A7). Int J Biochem Cell Biol 30: 567-571, 1998.

9. Jinquan T, Vorum H, Larsen CG, Madsen P, Rasmussen HH, Gesser B, Etzerodt M, Honoré B, Celis JE and ThestrupPedersen K: Psoriasin: A novel chemotactic protein. J Invest Dermatol 107: 5-10, 1996.

10. Enerbäck C, Porter DA, Seth P, Sgroi D, Gaudet J, Weremowicz S, Morton CC, Schnitt S, Pitts RL, Stampl J, et al: Psoriasin expression in mammary epithelial cells in vitro and in vivo. Cancer Res 62: 43-47, 2002.

11. Zhou G, Xie TX, Zhao M, Jasser SA, Younes MN, Sano D, Lin J, Kupferman ME, Santillan AA, Patel V, et al: Reciprocal negative regulation between S100A7/psoriasin and beta-catenin signaling plays an important role in tumor progression of squamous cell carcinoma of oral cavity. Oncogene 27: 3527-3538, 2008.

12. Deol YS, Nasser MW, Yu L, Zou X and Ganju RK: Tumorsuppressive effects of psoriasin (S100A7) are mediated through the $\beta$-catenin/T cell factor 4 protein pathway in estrogen receptor-positive breast cancer cells. J Biol Chem 286 : 44845-44854, 2011

13. Zhang H, Zhao Q, Chen Y, Wang Y, Gao S, Mao Y, Li M, Peng A, He D and Xiao X: Selective expression of S100A7 in lung squamous cell carcinomas and large cell carcinomas but not in adenocarcinomas and small cell carcinomas. Thorax 63: 352-359, 2008

14. Huang $\mathrm{L}, \mathrm{Wu} \mathrm{RL}$ and $\mathrm{Xu} \mathrm{AM}$ : Epithelial-mesenchymal transition in gastric cancer. Am J Transl Res 7: 2141-2158, 2015.

15. Moubayed N, Weichenthal M, Harder J, Wandel E, Sticherling M and Gläser R: Psoriasin (S100A7) is significantly up-regulated in human epithelial skin tumours. J Cancer Res Clin Oncol 133: 253-261, 2007
16. Tripathi SC, Matta A, Kaur J, Grigull J, Chauhan SS, Thakar A, Shukla NK, Duggal R, DattaGupta S, Ralhan R, et al: Nuclear S100A7 is associated with poor prognosis in head and neck cancer. PLoS One 5: e11939, 2010.

17. Ye L, Sun PH, Martin TA, Sanders AJ, Mason MD and Jiang WG: Psoriasin (S100A7) is a positive regulator of survival and invasion of prostate cancer cells. Urol Oncol 31: 1576-1583, 2013.

18. Tian T, Li X, Hua Z, Ma J, Wu X, Liu Z, Chen H and Cui Z: S100A7 promotes the migration, invasion and metastasis of human cervical cancer cells through epithelial-mesenchymal transition. Oncotarget 8: 24964-24977, 2017.

19. Nasser MW, Wani NA, Ahirwar DK, Powell CA, Ravi J, Elbaz M, Zhao H, Padilla L, Zhang X, Shilo K, et al: RAGE mediates S100A7-induced breast cancer growth and metastasis by modulating the tumor microenvironment. Cancer Res 75: 974-985, 2015.

20. Emberley ED, Niu Y, Curtis L, Troup S, Mandal SK, Myers JN, Gibson SB, Murphy LC and Watson PH: The S100A7-c-Jun activation domain binding protein 1 pathway enhances prosurvival pathways in breast cancer. Cancer Res 65: 5696-5702, 2005.

21. Edge SB and Compton CC: The American Joint Committee on Cancer: the 7th edition of the AJCC cancer staging manual and the future of TNM. Ann Surg Oncol 17: 1471-1474, 2010.

22. Keese CR, Wegener J, Walker SR and Giaever I: Electrical wound-healing assay for cells in vitro. Proc Natl Acad Sci USA 101: 1554-1559, 2004

23. Szulcek R, Bogaard HJ and van Nieuw Amerongen GP: Electric cell-substrate impedance sensing for the quantification of endothelial proliferation, barrier function, and motility. Journal of visualized experiments. J Vis Exp 85: 51300, 2014.

24. Wegener J, Keese CR and Giaever I: Electric cell-substrate impedance sensing (ECIS) as a noninvasive means to monitor the kinetics of cell spreading to artificial surfaces. Exp Cell Res 259: 158-166, 2000.

25. Keates S, Sougioultzis S, Keates AC, Zhao D, Peek RM Jr, Shaw LM and Kelly CP: cag+ Helicobacter pylori induce transactivation of the epidermal growth factor receptor in AGS gastric epithelial cells. J Biol Chem 276: 48127-48134, 2001.

26. Akagi T and Kimoto T: Human cell line (HGC-27) derived from the metastatic lymph node of gastric cancer. Acta Med Okayama 30: 215-219, 1976.

27. Nieto MA, Huang RY, Jackson RA and Thiery JP: EMT: 2016 Cell 166: 21-45, 2016.

28. Chambard JC, Lefloch R, Pouysségur J and Lenormand P: ERK implication in cell cycle regulation. Biochim Biophys Acta 1773: 1299-1310, 2007.

29. Jiang WG, Watkins G, Douglas-Jones A and Mansel RE: Psoriasin is aberrantly expressed in human breast cancer and is related to clinical outcomes. Int J Oncol 25: 81-85, 2004.

30. Liu Y, Bunston C, Hodson N, Resaul J, Sun PH, Cai S, Chen G, $\mathrm{Gu}$ Y, Satherley LK, Bosanquet DC, et al: Psoriasin promotes invasion, aggregation and survival of pancreatic cancer cells; association with disease progression. Int J Oncol 50: 1491-1500, 2017.

31. Kalluri R and Neilson EG: Epithelial-mesenchymal transition and its implications for fibrosis. J Clin Invest 112: 1776-1784, 2003.

32. Son $\mathrm{H}$ and Moon A: Epithelial-mesenchymal transition and cell invasion. Toxicol Res 26: 245-252, 2010.

33. Scanlon CS, Van Tubergen EA, Inglehart RC and D'Silva NJ: Biomarkers of epithelial-mesenchymal transition in squamous cell carcinoma. J Dent Res 92: 114-121, 2013

34. McCubrey JA, Steelman LS, Chappell WH, Abrams SL, Wong EW, Chang F, Lehmann B, Terrian DM, Milella M, Tafuri A, et al: Roles of the Raf/MEK/ERK pathway in cell growth, malignant transformation and drug resistance. Biochim Biophys Acta 1773: 1263-1284, 2007.

35. Steelman LS, Chappell WH, Abrams SL, Kempf RC, Long J, Laidler P, Mijatovic S, Maksimovic-Ivanic D, Stivala F, Mazzarino MC, et al: Roles of the Raf/MEK/ERK and PI3K/ PTEN/Akt/mTOR pathways in controlling growth and sensitivity to therapy-implications for cancer and aging. Aging (Albany NY) 3: 192-222, 2011

36. Abrams SL, Steelman LS, Shelton JG, Wong EW, Chappell WH, Bäsecke J, Stivala F, Donia M, Nicoletti F, Libra M, et al: The Raf/MEK/ERK pathway can govern drug resistance, apoptosis and sensitivity to targeted therapy. Cell Cycle 9: 1781-1791, 2010.

37. Shiota M, Tsunoda T, Song Y, Yokomizo A, Tada Y, Oda Y and Naito S: Enhanced S100 calcium-binding protein P expression sensitizes human bladder cancer cells to cisplatin. BJU Int 107: 1148-1153, 2011. 
38. Acharyya S, Oskarsson T, Vanharanta S, Malladi S, Kim J, Morris PG, Manova-Todorova K, Leversha M, Hogg N, Seshan VE, et al: A CXCL1 paracrine network links cancer chemoresistance and metastasis. Cell 150: 165-178, 2012.

39. Arumugam T, Ramachandran V, Sun D, Peng Z, Pal A Maxwell DS, Bornmann WG and Logsdon CD: Designing and developing S100P inhibitor 5-methyl cromolyn for pancreatic cancer therapy. Mol Cancer Ther 12: 654-662, 2013.
40. Zagryazhskaya A, Surova O, Akbar NS, Allavena G, Gyuraszova K, Zborovskaya IB, Tchevkina EM and Zhivotovsky B: Tudor staphylococcal nuclease drives chemoresistance of non-small cell lung carcinoma cells by regulating S100A11. Oncotarget 6: 12156-12173, 2015.

41. Dai Z, Huang Y and Sadée W: Growth factor signaling and resistance to cancer chemotherapy. Curr Top Med Chem 4: 1347-1356, 2004. 